\title{
Botanical galactogogues: nutritional values and therapeutic potentials
}

\author{
Gbadamosi. I. T. and Okolosi O.
}

Department of Botany, University of Ibadan, Ibadan, Nigeria

${ }^{*}$ Corresponding author: Idayat T. Gbadamosi Email: gita4me2004@yahoo.com

Department of Botany, University of Ibadan, Ibadan, Nigeria. Tel. 08035505173 / 07056114030 ,

Original submitted in on $2^{\text {nd }}$ November 2012. Published online at www.m.elewa.org on 31st January 2013.

\begin{abstract}
Objective: In view of the reported side effects of the orthodox galactogogues, this study analysed ten botanical galactogogues for their chemical constituents and antimicrobial activities with the aim of providing scientific insight into their use as galactogogues.

Methodology: The plants were identified at University of Ibadan Herbarium (UIH). Powdered plant samples were screened for chemical compositions using standard methods. The test organisms were clinical pathogenic isolates of Escherichia coli, Klebsiella pneumoniae, Pseudomonas aeruginosa, Candida albicans, Streptococcus pyogenes and Staphylococcus aureus. The ethanol extracts (50\%) of samples were prepared using cold extraction method and tested in vitro against isolates using agar well diffusion method. Alternanthera sessilis had the highest $(17.60 \mathrm{mg} / 100 \mathrm{~g})$ crude protein. Vitex doniana had the least $(15.36 \mathrm{mg} / 100 \mathrm{~g})$ crude fibre. V. doniana contained $1.46 \mathrm{mg} / 100 \mathrm{~g}$ of iron. A. digitata contained calcium $(5275.00 \mathrm{mg} / 100 \mathrm{~g})$. Lecaniodiscus cupanioides showed highest $(15.00 \mathrm{~mm})$ activity against Escherichia coli. V. doniana was most active against Klebsiella pneumoniae $(21.00 \mathrm{~mm})$.

Conclusions and application of findings: This study has contributed to preservation of indigenous knowledge of the use of botanicals as galactogogues. The test plants may not only work as galactagogues but also carry out multifunctional activity in the nursing mother and the child. Adansonia digitata can be used as weaning food due to its high calcium content. Vitex doniana could be used as food supplement based on its iron component. It could also have therapeutic application in anaemia related diseases or health condition in nursing mother especially Insufficient Milk Supply (IMS). The plants showed therapeutic potentials against $E$. coli and $K$. pneumoniae. They could be used for the treatment of diarrhoea and pneumonia reportedly to be major causes of child mortality worldwide. Further work should confirm the activity of these plants as galactagogues. The isolation and identification of active compounds of the test plants will contribute immensely to their use as herbal drugs.

Keywords: Botanicals, galactogogues, macronutrients, micronutrients, phytochemicals, antimicrobial activity.
\end{abstract}




\section{INTRODUCTION}

Vitex doniana (Sweet) (black plum), Kigelia africana (Lam.) Benth. (sausage tree), Allophylus africanus P.Beauv (African false currant), Alternanthera sessilis (L.) R. Br. (sessile joyweed), Secamone afzelii (Schult.) K. Schum. (secamore), Calotropis procera (Aiton) W. T. Aiton (sodom apple), Adansonia digitata Linn. (baobab tree), Lecaniodiscus cupanioides Planch. (ginger lily), Launaea taraxacifolia (Willd.) Amin ex C. Jeffrey (wild lettuce), and Senecio biafrae Oliv. \& Hiern (groundsel) are botanical galactogogues in Nigeria. Galactogogues are agents or substances that can induce or enhance breast milk secretion. They include foods, herbal medicines and pharmaceutical drugs. They can be helpful in solving milk supply issues not only by increasing milk production, but also by supporting the nursing mother's confidence (Westfall, 2003). Breastfeeding is an unequalled way of providing ideal food for healthy growth and development of infants, and exclusive breastfeeding is the optimal way of feeding infants (Kramer and Kakuma, 2002). It provides all the energy and nutrients that the infant needs for the first months of life, and it continues to provide up to half or more of a child's nutritional needs during the second half of the first year, and up to one-third during the second year of life. Breast-feeding is associated with better nutritional and non-nutritional outcomes compared with formula feeding even in case of preterm birth (Chatterton et al., 2000). The World Health Organisation strongly recommends exclusive breastfeeding for the first six months of life. After six months, other foods should complement breastfeeding for up to two years or more. Beyond the immediate benefits for children, breastfeeding contributes to a lifetime of good health (WHO, 2012). Lactating mothers face a variety of challenges including maintaining a sufficient milk supply (Henderson, 2003). Insufficient Milk Supply (IMS) is the major reason cited for early cessation of breastfeeding; yet actual insufficient milk supply is rare, as IMS is associated with insufficient glandular tissue, breast surgery, postpartum haemorrhage or anaemia (Riordan and Acerbic, 1998). A reduced breast milk production can occur in many circumstances, such as preterm birth, illness of the mother or the child, mother-baby separation, relactation after a prolonged suspension, indirect lactation (breast pump or manual milk expression), anxiety, fatigue, and emotional stress are powerful inhibitors of lactation (Zuppa et al., 2010). Imbalance in maternal hormone, deficiency in the breast tissue itself or most often inadequate milk removal due to poor breast feeding techniques can also reduce breast milk production (Mohrbacher and Stock, 2003). Lactating mothers should consume a wellbalanced diet, maintain adequate fluid intake and avoid substances known to decrease milk supply. A diet with increased protein (Lawrence, 1999) and approximately 500 extra calories above what they need to maintain their weight will promote maximum milk production (Riordan and Auerbach, 1998). Maternal micronutrient deficiencies during lactation can cause a major reduction in the concentration of some of these nutrients in breast milk, with subsequent infant depletion (Allen and Graham, 2003). The main mineral constituents of human milk are Sodium $(\mathrm{Na})$, Potassium $(\mathrm{K})$, Calcium $(\mathrm{Ca})$, Magnesium (Mg), Phosphorus (P), and Chlorine (Cl). Calcium concentrations reported in various studies vary from $25-35 \mathrm{mg} / 100 \mathrm{ml}$. Phosphorus at $13-16$ $\mathrm{mg} / 100 \mathrm{ml}$ is much more constant but is lower in proportion to casein and calcium than in milks of most other animal species. Iron, copper, and zinc contents of human milk vary considerably and a long list of other trace elements has been reported. All of the vitamins except vitamin $\mathrm{K}$ are found in human milk in nutritionally significant concentrations (Jenness, 1979). Breast fed babies are highly protected against diseases due to antibodies present in breast milk (Newman, 1995). In addition to individual health benefits, breastfeeding may provide significant economic benefits in terms of reducing costs that may be related to visiting the physician, clinic, hospital, or medical Laboratory. Other direct economic benefits to a family may be not buying or reduced cost of buying infant formula for the first year after birth (Weimer, 2001). Some orthodox galactogogues are metoclopramide, domperidone and chlorpromazine. The side effects of 

potentials

metoclopramide are fatigue, irritability and depression (Starr and Starr, 1999). Domperidone has been reported to cause cardiac arrhythmia and sudden death in cancer patients treated with intravenous domperidone (Osborne et al., 1985). Chlorpromazine has side effects of weight gain and lethargy, sleepiness and reduced behavioural performance in infants (Henderson, 2003).

The use of natural products in inducing and increasing milk production has a long history (Zuppa, 2010) and nearly all cultures have promoted one substance or another as a galactogogue to encourage the synthesis and secretion of breast milk

\section{MATERIALS AND METHODS}

Ethnobotanical information: The selection of medicinal plants for this study was based on ethnobotanical information from literature and oral interview of local herbsellers on plant used as galactogogues. The interview was carried out at a local herbal market (Bode) in Ibadan, Oyo state, Nigeria.

Collection and Identification of plant materials: Launaea taraxacifolia (leaf) and Senecio biafrae (leaf) were purchased from a local herbal market (Bode) in Ibadan, while Vitex doniana (fruit), Allophylus africanus (leaf), Alternanthera sessilis (leaf), Secamone afzelii (leaf), Calotropis procera (stem), Adansonia digitata (bark), Lecaniodiscus cupanioides (root), and Kigelia africana (fruit) were collected from University of Ibadan campus. The test plants were identified at species level in the University of Ibadan Herbarium (UIH).

Preparation of plant materials for analysis: The test plants were washed, cut into small pieces and dried at room temperature $\left(30^{\circ} \mathrm{C}\right)$ for three weeks until completely dried. The dry plant materials were ground into powder and stored in air-tight glass bottles at room temperature $\left(30^{\circ} \mathrm{C}\right)$ for further use.

Proximate analysis: The methods described in AOAC (2005) were used to analyse the proximate composition of the plants for crude protein, crude fat, crude fibre, moisture and ash while carbohydrate was calculated by subtracting the sum of the values of the other nutrients from 100.

Micronutrient analysis: Micronutrient analysis was carried out after wet digestion. The method of Walsh (1971) was used for digestion of all plant samples. After digestion Calcium (Ca), Magnesium (Mg), Copper (Cu), Zinc $(\mathrm{Zn})$, Iron ( $\mathrm{Fe})$, Sodium ( $\mathrm{Na})$, Potassium $(\mathrm{K})$, Manganese (Mn) were analysed using Atomic Absorption
(Henderson, 2003). Many botanical galactogogues are derived from plant producing latex (milky sap) or whose shape resemble the breast (doctrine of signature). The drugs are, in their majority, not exclusively employed to increase the flow of breast milk but serve as multi-functional remedies (Perry, 1980), their use occasionally finds a parallel in popular veterinary practice to stimulate milk production in cattle and other mammals (Bruckner, 1993). This study was designed to evaluate the nutritional values and therapeutic potentials of ten botanical galactogogues with a view to providing scientific insight into their use.

Spectrophotometer (FC 210/211 VGP Bausch scientific AAS). Phosphorus was determined using Vanadomolybdate (Yellow method.) (AOAC, 2005). Percentage transmittance was determined at $400 \mathrm{~nm}$ using Spectronic 20 (Bausch and Lomb) Colorimeter.

Phytochemical analysis: Phytochemical tests were carried out using standard procedure described by Harbone (1973), Sofowora (1993) and Evans (2002).

Extraction of powdered plant samples in ethanol: The powdered plant sample (50g each) was extracted in 300 $\mathrm{ml}$ of ethanol for 2 weeks using cold extraction methods. The extract was concentrated at $40^{\circ} \mathrm{C}$ and stored in the refrigerator $\left(4^{\circ} \mathrm{C}\right)$ prior to use. $100 \mathrm{mg} / \mathrm{ml}$ of the extract was used for the antimicrobial screening.

Antimicrobial screening: The test organisms were clinical isolates of Escherichia coli, Klebsiella pneumoniae, Pseudomonas aeruginosa, Candida albicans, Streptococcus pyogenes, and Staphylococcus aureus obtained from University College Hospital (UCH), Ibadan. Isolates were maintained in cultures on Nutrient Agar (Quebec, Canada). The isolates were grown in nutrient broth (Quebec, Canada) for $18 \mathrm{~h}$. at $35^{\circ} \mathrm{C}$. The inoculum load was adjusted to $1 \times 10^{-3} \mathrm{cfu} / \mathrm{ml}$ via serial dilution method prior to use. $1 \mathrm{ml}$ of the inoculum was thoroughly mixed with $19 \mathrm{ml}$ of sterile nutrient agar and poured into sterile Petri dish (100 mm in diameter). The agar was left to solidify. A standard cork borer of $6 \mathrm{~mm}$ in diameter was used to cut well in each agar plate. Thirty (30) $\mu$ l of each extract was filled into the wells with the aid of a sterile micropipette. Fifty (50) \% ethanol was used instead of the extract in the control experiment. Also plates containing the test organisms in agar without extract were used as control. All experiments were done aseptically and each experiment was replicated three 

potentials

times. The plates were incubated at $37^{\circ} \mathrm{C}$ for $36-48 \mathrm{hrs}$. The diameters of the clear zones of inhibitions were measured and the result recorded in millimetres $(\mathrm{mm})$.

Statistical analysis: All data were expressed as mean \pm SD and statistically analysed using One-way Analysis of RESULTS AND DISCUSSION

The profiles of the ten botanical galactogogues are presented in Table 1. The plants belong to eight different families namely: Verbenaceae, Bignoniaceae, Sapindaceae, Amaranthaceae, Asclepiadaceae, Bombacaceae, Sapindaceae, and Asteraceae. Future
Variance (ANOVA). The Duncan Multiple Range Test (DMRT) was used to test means for significance. Values were considered significant at $\mathrm{P}<0.05$.

search for galactogogues should include the botanicals from these families most especially the Asclepiadaceae and Asteraceae which are common. The habits (life forms) of the plants were $50 \%$ trees, $40 \%$ herbs and $10 \%$ shrubs.

Table 1: Profile of botanical galactogogues used in this study

\begin{tabular}{l|l|l|l|l|l}
\hline $\mathbf{S} / \mathbf{N}$ & Plant & Family & $\begin{array}{l}\text { Local name } \\
\text { (Yoruba) }\end{array}$ & Plant habit & Part used \\
\hline $\mathbf{1 .}$ & Vitex doniana & Verbenaceae & Oori-nla & Tree & Fruits \\
$\mathbf{2 .}$ & Kigelia africana & Bignoniaceae & Pandoro & Tree & Fruits \\
$\mathbf{3 .}$ & Allophylus africanus & Sapindaceae & Eekan-ehoro & Small tree & Leaves \\
$\mathbf{4 .}$ & Alternanthera sessilis & Amaranthaceae & Reku-reku & Herb & Leaves \\
$\mathbf{5 .}$ & Secamone afzelii & Asclepiadaceae & Arilu,alu & Herb & Leaves \\
$\mathbf{6 .}$ & Calotropis procera & Asclepiadaceae & Bomubomu & Shrub & Stems \\
$\mathbf{7 .}$ & Adansonia digitata & Bombacaceae & Ose & Tree & Barks \\
$\mathbf{8 .}$ & Lecaniodiscus cupanioides & Sapindaceae & Akika & Small tree & Roots \\
$\mathbf{9 .}$ & Launaea taraxacifolia & Asteraceae & Yanrin & Herb & Leaves \\
$\mathbf{1 0 .}$ & Senecio biafrae & Asteraceae & Worowo & Herb & Leaves \\
\hline
\end{tabular}

Table 2 shows the indigenous recipes and their methods of preparation and administration. The methods of preparation are decoction, concoction and paste. The decoctions are taken orally, concoction are eaten as vegetable and paste are applied topically on the breast.

Table 2: Method of preparation and administration of indigenous galactogogue recipes

\begin{tabular}{|c|c|c|}
\hline S/N & Herbal combination and dosage (ml) & $\begin{array}{l}\text { Method of } \\
\text { preparation }\end{array}$ \\
\hline 1 & $\begin{array}{l}\text { Vitex doniana fruits and leaves are boiled in water and } 200 \mathrm{ml} \text { taken three times daily after meal } \\
\text { to induce lactation. }\end{array}$ & Decoction \\
\hline 2 & $\begin{array}{l}\text { The ripe fruit of Kigelia africana is made into a paste and massaged on the breast. A decoction } \\
\text { ( } 200 \mathrm{ml} \text { ) of the fruit is taken twice daily to induce secretion of breast milk. }\end{array}$ & $\begin{array}{l}\text { Decoction and } \\
\text { paste }\end{array}$ \\
\hline 3 & $\begin{array}{l}\text { The bark and leaves of Allophylus africanus are boiled in water and } 200 \mathrm{ml} \text { taken twice daily } \\
\text { after meal. }\end{array}$ & Decoction \\
\hline 4 & $\begin{array}{l}\text { The leaves of Alternanthera sessilis are eaten as vegetable in soup to enhance secretion of } \\
\text { breast milk. The leaves could also be squeezed in water as drink. }\end{array}$ & Concoction \\
\hline 5 & Secamone afzelii leaves are made into paste and rubbed on the breast. & Paste \\
\hline 6 & Stems of Calotropis procera are boiled in water and $150 \mathrm{ml}$ taken twice daily after meal. & Decoction \\
\hline 7 & The bark of Adansonia digitata is boiled in water and $200 \mathrm{ml}$ taken twice daily after meal. & Decoction \\
\hline 8 & $\begin{array}{l}\text { The roots of Lecaniodiscus cupanioides are boiled in water and } 100 \mathrm{ml} \text { taken twice daily after } \\
\text { meal. }\end{array}$ & Decoction \\
\hline 9 & Leaves of Launaea taraxacifolia are eaten as vegetable in soup. & Concoction \\
\hline 10 & Leaves of Senecio biafrae are eaten as vegetable in soup. & Concoction \\
\hline
\end{tabular}


The proximate analysis revealed that some of the plants were high in protein (Table 3). The crude protein content of $A$. sessilis (17.60\%) was significantly high and the least $(9.79 \%)$ was from $A$. digitata. Food that provide more than $12 \%$ of the calorific value from protein are good sources of protein and proteins are very important molecules in human being and are involved in virtually all cell functions (Lioyd, 2012), in that context Vitex doniana, Allophylus africanus, Alternanthera sessilis, Secamone afzelii, Launaea taraxacifolia and Senecio biafrae are good sources of protein. Crude fat was highest in $C$. procera $(8.64 \%)$ followed by S. afzelii $(7.05 \%)$ while $A$. digitata $(3.62 \%)$ had the lowest.

Table 3: Proximate compositions of ten botanical galactogogues

\begin{tabular}{|c|c|c|c|c|c|c|}
\hline Plant & $\begin{array}{l}\text { Crude } \\
\text { protein } \\
(\%)\end{array}$ & $\begin{array}{l}\text { Crude } \\
\text { fat } \\
(\%)\end{array}$ & $\begin{array}{l}\text { Crude fibre } \\
(\%)\end{array}$ & $\begin{array}{l}\text { Moisture } \\
(\%)\end{array}$ & $\begin{array}{l}\text { Ash } \\
(\%)\end{array}$ & $\begin{array}{l}\text { Carbo- } \\
\text { hydrate } \\
(\%)\end{array}$ \\
\hline Vitex doniana & ${ }^{*} 12.38 \mp \pm 0.10$ & $5.13^{f} \pm 0.03$ & $15.36 \pm 0.03$ & $9.139 \pm 0.02$ & $6.06^{\mathrm{e}} \pm 0.02$ & $51.94^{b} \pm 0.05$ \\
\hline Kigelia Africana & $6.74 \pm 0.004$ & $3.66^{i} \pm 0.03$ & $36.83^{a} \pm 0.02$ & $9.29^{f} \pm 0.03$ & $4.919 \pm 0.03$ & $27.22^{j} \pm 0.09$ \\
\hline Allophylus africanus & $16.91^{b} \pm 0.05$ & $6.82^{c} \pm 0.03$ & $17.76^{d} \pm 0.03$ & $9.54^{d} \pm 0.02$ & $11.8^{b} \pm 0.02$ & $37.13^{i} \pm 0.12$ \\
\hline Alternanthera sessilis & $17.60^{\mathrm{a}} \pm 0.06$ & $5.61^{\mathrm{e}} \pm 0.03$ & $16.419 \pm 0.03$ & $9.26^{f} \pm 0.03$ & $12.44^{\mathrm{a}} \pm 0.00$ & $38.679 \pm 0.45$ \\
\hline Secamone afzelii & $15.89^{c} \pm 0.10$ & $7.05^{b} \pm 0.03$ & $17.27^{e} \pm 0.03$ & $9.70^{c} \pm 0.00$ & $11.96^{b} \pm 0.00$ & $38.13^{h} \pm 0.11$ \\
\hline Calotropis procera & $9.399 \pm 0.07$ & $8.64^{a} \pm 0.03$ & $21.52^{c} \pm 0.03$ & $9.94^{\mathrm{a}} \pm 0.02$ & $5.34^{f} \pm 0.03$ & $45.17^{\mathrm{e}} \pm 0.10$ \\
\hline Adansonia digitata & $5.52^{j} \pm 0.04$ & $3.62^{i} \pm 0.03$ & $16.94^{f} \pm 0.03$ & $9.79^{b} \pm 0.03$ & $4.07^{\mathrm{h}} \pm 0.02$ & $60.06^{\mathrm{a}} \pm 0.10$ \\
\hline $\begin{array}{l}\text { Lecaniodiscus } \\
\text { cupanioides }\end{array}$ & $7.29^{h} \pm 0.06$ & $6.17^{d} \pm 0.02$ & $29.47^{b} \pm 0.02$ & $9.21^{f} \pm 0.04$ & $3.51^{i} \pm 0.02$ & $44.35^{\dagger} \pm 0.07$ \\
\hline Launaea taraxacifolia & $13.47^{\mathrm{d}} \pm 0.09$ & $4.73^{g} \pm 0.03$ & $15.54^{\mathrm{h}} \pm 0.02$ & $9.15^{g} \pm 0.04$ & $9.86^{c} \pm 0.02$ & $47.25^{d} \pm 0.11$ \\
\hline Senecio biafrae & $12.94^{e} \pm 0.02$ & $4.33^{h} \pm 0.03$ & $17.23^{e} \pm 0.02$ & $9.43^{\mathrm{e}} \pm 0.04$ & $6.20^{d} \pm 0.02$ & $49.87^{c} \pm 0.07$ \\
\hline
\end{tabular}

Legend: Values are mean \pm SD of three replicates. Test values in the same column with same superscripts are not significantly different at $P<0.05$.

The high crude fat observed in C. procera and S. afzelii may be due to the considerable amount of latex present in two plants; this may be an indication that latexproducing plants are high in crude fat. Fats are the principal sources of energy and one gram of lipid provides $9.0 \mathrm{Kcal}(37.33 \mathrm{KJ})$ of energy (FAO, 2003). The highest crude fibre was observed in $K$. africana $(36.83 \%)$ followed by L. cupanioides $(29.47 \%)$ and V. doniana $(15.36 \%)$ had the lowest. Crude fibre is an important part of diet and decreases serum cholesterol level, risk of coronary heart disease, hypertension, diabetes, colon and breast cancer (Ishida et al., 2000). This indicates that the fibre (roughage) content of these plants such as $K$. africana, $L$. cupanioides, and $\mathrm{C}$. procera will promote digestion and prevent constipation when consumed.

The plant samples contained varied amount of micronutrients (Table 4). Sodium ( $\mathrm{Na}$ ) content was highest in A. sessilis $(646.00 \mathrm{mg} / 100 \mathrm{~g})$ followed by $C$. procera $(533.00 \mathrm{mg} / 100 \mathrm{~g})$ and $L$. cupanioides had the lowest $(13.60 \mathrm{mg} / 100 \mathrm{~g})$. The highest calcium (Ca) content was from A. digitata $(5275.00 \mathrm{mg} / 100 \mathrm{~g})$ followed by S. afzelii $(4050.00 \mathrm{mg} / 100 \mathrm{~g})$ and the least $(45.00 \mathrm{mg} /$ $100 \mathrm{~g}$ ) from $V$. doniana. The high amount of calcium in the bark of $A$. digitata is in agreement with the report of Lockett et al. (2000) who reported that the bark of $A$. digitata was high in calcium. Calcium rich plants in diets are known to aid strong bones and healthy teeth formation. Iron content was highest in V. doniana (1.46 $\mathrm{mg} / 100 \mathrm{~g})$ followed by $A$. sessilis $(0.777 \mathrm{mg} / 100 \mathrm{~g})$ and $K$. africana had the least $(0.12 \mathrm{mg} / 100 \mathrm{~g})$. The Iron constituent in Vitex doniana in this study agrees with the report of Nnamani et al. (2009) that the amount of iron in $V$. doniana leaves was less than $4 \mathrm{mg} / 100 \mathrm{~g}$. Intake of food rich in iron will prevent anaemia and fatigue. 
Gbadamosi and Okolosi. J. Appl. Biosci. 2013. Botanical galactogogues: Nutritional and therapeutic potentials

Table 4: Micronutrient components of ten botanical galactogogues $(\mathrm{mg} / 100 \mathrm{~g})$

\begin{tabular}{|c|c|c|c|c|c|c|c|c|c|}
\hline Plant & $\mathrm{Na}$ & $\mathrm{Ca}$ & $\mathrm{Fe}$ & $\mathbf{P}$ & $\mathrm{K}$ & $\mathrm{Zn}$ & $\mathrm{Cu}$ & $\mathrm{Mg}$ & Mn \\
\hline $\begin{array}{l}\text { Vitex } \\
\text { doniana }\end{array}$ & $\begin{array}{l}* 27.70^{\mathrm{h}} \\
\pm 0.01\end{array}$ & $\begin{array}{l}45.00^{\mathrm{j}} \\
\pm 0.20\end{array}$ & $\begin{array}{l}1.46^{\mathrm{a}} \\
\pm 0.01\end{array}$ & $\begin{array}{c}65.60^{i} \\
\pm 0.35\end{array}$ & $\begin{array}{l}228.50^{\mathrm{e}} \\
\pm 0.11\end{array}$ & $\begin{array}{r}1.69^{h} \\
\pm 0.00\end{array}$ & $\begin{array}{r}0.65^{\dagger} \\
\pm 0.00\end{array}$ & $\begin{array}{l}129.00 \mathrm{j} \\
\pm 0.15\end{array}$ & $\begin{array}{r}0.40^{i} \\
\pm 0.01\end{array}$ \\
\hline Kigelia Africana & $\begin{array}{l}41.10^{f} \\
\pm 0.02\end{array}$ & $\begin{array}{l}446.00^{\circ} \\
\pm 0.06\end{array}$ & $\begin{array}{l}0.12^{\mathrm{j}} \\
\pm 0.00\end{array}$ & $\begin{array}{l}72.20 \mathrm{~g} \\
\pm 0.17\end{array}$ & $\begin{array}{l}79.30^{\mathrm{h}} \\
\pm 0.04\end{array}$ & $\begin{array}{r}1.70^{\mathrm{h}} \\
\pm 0.01\end{array}$ & $\begin{array}{r}1.03^{\mathrm{d}} \\
\pm 0.00\end{array}$ & $\begin{array}{c}165.00 \\
\pm 0.16\end{array}$ & $\begin{array}{r}0.20 \mathrm{j} \\
\pm 0.01\end{array}$ \\
\hline $\begin{array}{l}\text { Allophylus } \\
\text { africanus } \\
\text { Alternanthera } \\
\text { sessilis }\end{array}$ & $\begin{array}{l}30.10 \mathrm{~g} \\
\pm 0.02 \\
646.00^{\mathrm{a}} \\
\pm 0.20\end{array}$ & $\begin{array}{l}2305.00^{\circ} \\
\pm 0.12 \\
2770.00^{\circ} \\
\pm 0.93\end{array}$ & $\begin{array}{c}0.30^{\mathrm{e}} \\
\pm 0.00 \\
0.777^{\mathrm{b}} \\
\pm 0.00\end{array}$ & $\begin{array}{l}109.40^{\mathrm{c}} \\
\pm 0.20 \\
94.10^{\mathrm{e}} \\
\pm 0.15\end{array}$ & $\begin{array}{l}77.80^{\mathrm{i}} \\
\pm 0.01 \\
668.50^{\mathrm{b}} \\
\pm 0.47\end{array}$ & $\begin{array}{r}5.01^{\mathrm{d}} \\
\pm 0.02 \\
9.81^{\mathrm{a}} \\
\pm 0.02\end{array}$ & $\begin{array}{l}1.04^{d} \\
\pm 0.00 \\
1.77^{c} \\
\pm 0.00\end{array}$ & $\begin{array}{l}662.00^{\mathrm{c}} \\
\pm 0.06 \\
1195.00^{\mathrm{a}} \\
\pm 0.01\end{array}$ & $\begin{array}{c}8.20^{\circ} \\
\pm 0.01 \\
19.30^{\circ} \\
\pm 0.01\end{array}$ \\
\hline $\begin{array}{l}\text { Secamone } \\
\text { afzelii }\end{array}$ & $\begin{array}{l}345.00^{\circ} \\
\pm 0.20\end{array}$ & $\begin{array}{l}4050.00^{\mathrm{b}} \\
\pm 0.17\end{array}$ & 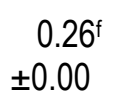 & $\begin{array}{l}98.40^{d} \\
\pm 0.10\end{array}$ & $\begin{array}{l}295.00^{d} \\
\pm 0.06\end{array}$ & $\begin{array}{r}2.97^{f} \\
\pm 0.01\end{array}$ & $\begin{array}{r}2.03^{\mathrm{a}} \\
\pm 0.00\end{array}$ & $\begin{array}{l}658.00^{\mathrm{d}} \\
\pm 0.22\end{array}$ & $\begin{array}{l}16.10^{\mathrm{b}} \\
\pm 0.01\end{array}$ \\
\hline $\begin{array}{l}\text { Calotropis } \\
\text { procera }\end{array}$ & $\begin{array}{l}533.00^{\mathrm{b}} \\
\pm 0.10\end{array}$ & $\begin{array}{l}1465.009 \\
\pm 1.53\end{array}$ & $\begin{array}{r}0.19^{h} \\
\pm 0.00\end{array}$ & $\begin{array}{l}91.90^{f} \\
\pm 0.15\end{array}$ & $\begin{array}{l}221.50^{f} \\
\pm 0.10\end{array}$ & $\begin{array}{r}2.749 \\
\pm 0.00\end{array}$ & $\begin{array}{r}0.94 e^{2} \\
\pm 0.00\end{array}$ & $\begin{array}{l}543.00^{f} \\
\pm 0.82\end{array}$ & $\begin{array}{r}3.80^{f} \\
\pm 0.01\end{array}$ \\
\hline $\begin{array}{l}\text { Adansonia } \\
\text { digitata }\end{array}$ & $\begin{array}{r}19.40^{\mathrm{i}} \\
\pm 0.01\end{array}$ & $\begin{array}{l}5275.00^{\mathrm{a}} \\
\pm 2.91\end{array}$ & $\begin{array}{r}0.219 \\
\pm 0.00\end{array}$ & $\begin{array}{l}70.00^{h} \\
\pm 0.07\end{array}$ & $\begin{array}{l}191.009 \\
\pm 0.01\end{array}$ & $\begin{array}{r}3.82^{\mathrm{e}} \\
\pm 0.01\end{array}$ & $\begin{array}{r}0.67^{f} \\
\pm 0.00\end{array}$ & $\begin{array}{l}714.50^{\mathrm{b}} \\
\pm 0.41\end{array}$ & $\begin{array}{r}7.80^{\mathrm{d}} \\
\pm 0.01\end{array}$ \\
\hline $\begin{array}{l}\text { Lecaniodiscus } \\
\text { cupanioides }\end{array}$ & $\begin{array}{r}13.60 \mathrm{j} \\
\pm 0.02\end{array}$ & $\begin{array}{l}450.00^{h} \\
\pm 2.52\end{array}$ & $\begin{array}{r}0.18 \\
\pm 0.00\end{array}$ & $\begin{array}{l}21.90^{\mathrm{j}} \\
\pm 1.18\end{array}$ & $\begin{array}{c}33.50 \mathrm{j} \\
\pm 0.01\end{array}$ & $\begin{array}{r}1.64 \\
\pm 0.02\end{array}$ & $\begin{array}{r}0.579 \\
\pm 0.00\end{array}$ & $\begin{array}{l}341.50^{\mathrm{h}} \\
\pm 0.32\end{array}$ & $\begin{array}{r}1.30^{\mathrm{h}} \\
\pm 0.03\end{array}$ \\
\hline $\begin{array}{l}\text { Launaea } \\
\text { taraxacifolia }\end{array}$ & $\begin{array}{l}237.00^{d} \\
\pm 0.01\end{array}$ & $\begin{array}{l}2315.00^{d} \\
\pm 0.15\end{array}$ & $\begin{array}{r}0.43^{d} \\
\pm 0.00\end{array}$ & $\begin{array}{l}123.00^{b} \\
\pm 0.06\end{array}$ & $\begin{array}{l}1044.00^{\mathrm{a}} \\
\pm 0.01\end{array}$ & $\begin{array}{r}5.89 c \\
\pm 0.01\end{array}$ & $\begin{array}{r}1.92^{\mathrm{b}} \\
\pm 0.00\end{array}$ & $\begin{array}{l}391.009 \\
\pm 1.29\end{array}$ & $\begin{array}{l}4.80^{\mathrm{e}} \\
\pm 0.03\end{array}$ \\
\hline Senecio biafrae & $\begin{array}{l}90.80^{\mathrm{e}} \\
\pm 0.01\end{array}$ & $\begin{array}{l}2110.00^{f} \\
\pm 0.53\end{array}$ & $\begin{array}{r}0.75^{c} \\
\pm 0.02\end{array}$ & $\begin{array}{l}155.30^{a} \\
\pm 0.05\end{array}$ & $\begin{array}{l}574.00^{c} \\
\pm 0.06\end{array}$ & $\begin{array}{r}8.41^{\mathrm{b}} \\
\pm 0.01\end{array}$ & $\begin{array}{r}1.89^{b} \\
\pm 0.00\end{array}$ & $\begin{array}{l}550.00^{e} \\
\pm 0.36\end{array}$ & $\begin{array}{l}3.20 \mathrm{~g} \\
\pm 0.01\end{array}$ \\
\hline
\end{tabular}

Legend: Values are mean \pm SD of three replicates. Test values in the same column with same superscripts are not significantly different at $\mathrm{P}<0.05$.

The plant samples contained alkaloids, tannins, $\beta$ carotene, saponins, and steroids in varied quantities (Table 5). The percentage phytochemical was low and in all cases less than 3.0 percent. This agrees with the report of Dike (2010) who recorded between 0.00 - 4.14 $\%$ phytochemicals in the fruits, seeds and leaves of some plant species (Adansonia digitata and Lecaniodiscus cupanioides). Alkaloids were highest in $L$. cupanioides $(1.15 \%)$ and lowest in C. procera $(0.33 \%)$. Alkaloids are known to play some metabolic role and control development in living system. It also has protective role in animals and used in medicine especially the steroidal alkaloids that constitute most of the valuable drugs (Edeoga et al., 2006). The amount of tannins was highest in V. doniana $(0.040 \%)$ and $K$. africana $(0.014 \%)$ had the least. A. sessilis $(1486.55 \mu \mathrm{g} / 100 \mathrm{~g})$ had the highest amount of $\beta$ carotene and $A$. digitata $(6.30 \mu \mathrm{g} / 100 \mathrm{~g})$ had the least. Tannins hasten the healing of wounds and inflamed mucus membrane, hence herbs possessing tannins are widely used as mouth wash, eye washes, snuff, vaginal douches and also to treat rectal disorder. Although, long term and excessive use of herbal vegetable containing high concentration of tannins is not recommended because when applied internally, tannins affect the walls of the stomach and other digestive parts, they sour the mucus secretions and contract or squeeze the membranes in such a manner that secretions from the cells are restricted (Okwu and Okwu, 2004). All the test plants had steroid, although in minute quantities. The presence of steroid may enhance the use of the plants as galactogogues by ensuring the synthesis of lactation hormones. According to Okwu (2001), steroids increase protein synthesis, promote growth of muscles and bones, and that steroidal compounds are of importance and interest in pharmacy due to their relationship with compounds such as sex hormones. Saponin was highest 
in $L$. cupanioides $(2.53 \%)$ and $C$. procera had the least $(0.54 \%)$. Saponins are produced by plants as defence mechanism to stop attack by foreign pathogen, thus making them to be natural antibiotics. Studies have shown that saponins can generate adverse physiological responses in animals that consume them. They exhibit cytotoxic effect and growth inhibition against a variety of cells, making them to have anti-inflammatory and anticancer properties (Iniaghe et al., 2009). They also show tumour inhibiting activity on animals (Akindahunsi and Salawu, 2005).

Table 5: Phytochemical compositions of ten botanical galactogogues

\begin{tabular}{|c|c|c|c|c|c|c|c|c|c|c|}
\hline Plant & $\begin{array}{l}\frac{2}{2} \\
\frac{0}{0} \\
\frac{0}{0} \\
\frac{0}{10} \\
\frac{10}{4}\end{array}$ & 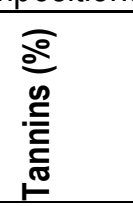 & 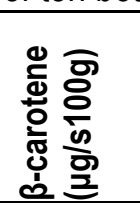 & 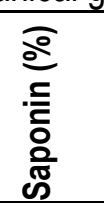 & $\begin{array}{l}\text { 응 } \\
\text { 응 } \\
\stackrel{0}{\frac{\pi}{4}} \widehat{巳}\end{array}$ & $\begin{array}{l}\widehat{O} \\
\frac{0}{0} \\
\frac{0}{0} \\
\frac{0}{0} \\
\text { के }\end{array}$ & 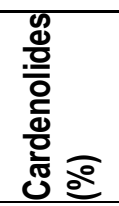 & 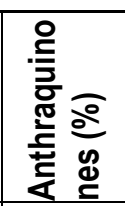 & $\begin{array}{l}\text { d } \\
\frac{0}{0} \\
\stackrel{0}{0} \\
\frac{0}{0}\end{array}$ & $\begin{array}{l}\bar{\Xi} \\
\overline{0} \\
\frac{0}{0} \\
\frac{5}{2}\end{array}$ \\
\hline $\begin{array}{l}\text { Vitex } \\
\text { doniana }\end{array}$ & $\begin{array}{l}{ }^{*} 0.37 \text { । } \\
\pm 0.020\end{array}$ & $\begin{array}{r}0.040^{\mathrm{a}} \\
\pm 0.001\end{array}$ & $\begin{array}{l}682.43 \mathrm{e} \\
\pm 0.02\end{array}$ & $\begin{array}{l}0.75^{f} \\
\pm 0.01\end{array}$ & $\begin{array}{r}0.002^{c} \\
\pm 0.000\end{array}$ & $\begin{array}{r}0.003^{f} \\
\pm 0.000\end{array}$ & $\begin{array}{r}0.006^{a} \\
\pm 0.000\end{array}$ & $\begin{array}{l}0.000 \mathrm{~g} \\
\pm 0.000\end{array}$ & $\begin{array}{l}0.400^{f} \\
\pm 0.010\end{array}$ & $0.085^{a}$ \\
\hline Kigelia Africana & $\begin{array}{l}1.03^{\mathrm{b}} \\
\pm 0.010\end{array}$ & $\begin{array}{l}0.0149 \\
\pm 0.003\end{array}$ & $\begin{array}{l}11.35^{i} \\
\pm 0.03\end{array}$ & $\begin{array}{l}2.35^{b} \\
\pm 0.03\end{array}$ & $\begin{array}{l}0.000^{d} \\
\pm 0.000\end{array}$ & $\begin{array}{r}0.001^{\mathrm{h}} \\
\pm 0.000\end{array}$ & $\begin{array}{l}0.000^{d} \\
\pm 0.000\end{array}$ & $\begin{array}{l}0.0009 \\
\pm 0.000\end{array}$ & $\begin{array}{l}0.780^{\mathrm{a}} \\
\pm 0.030\end{array}$ & $\begin{array}{c} \pm 0.002 \\
0.040^{\mathrm{d}} \\
\pm 0.001\end{array}$ \\
\hline $\begin{array}{l}\text { Allophylus } \\
\text { africanus }\end{array}$ & $\begin{array}{l}0.56^{f} \\
\pm 0.020\end{array}$ & $\begin{array}{l}0.023^{\mathrm{e}} \\
\pm 0.002\end{array}$ & $\begin{array}{l}1346.64^{b} \\
\pm 0.03\end{array}$ & $\begin{array}{l}0.86^{e} \\
\pm 0.03\end{array}$ & $\begin{array}{l}0.006^{a} \\
\pm 0.000\end{array}$ & $\begin{array}{l}0.004 \mathrm{e} \\
\pm 0.000\end{array}$ & $\begin{array}{l}0.000^{d} \\
\pm 0.000\end{array}$ & $\begin{array}{l}0.066^{b} \\
\pm 0.002\end{array}$ & $\begin{array}{l}0.350 \mathrm{~g} \\
\pm 0.020\end{array}$ & $0.047^{c}$ \\
\hline $\begin{array}{l}\text { Alternanthera } \\
\text { sessilis }\end{array}$ & $\begin{array}{l}0.80^{c} \\
+0.010\end{array}$ & $\begin{array}{l}0.018^{f} \\
+0.001\end{array}$ & $\begin{array}{l}1486.55^{a} \\
+0.02\end{array}$ & $\begin{array}{l}1.23^{c} \\
+0.03\end{array}$ & $\begin{array}{r}0.002^{c} \\
+0000\end{array}$ & $\begin{array}{r}0.007^{\mathrm{b}} \\
+0.000\end{array}$ & $0.000^{d}$ & $\begin{array}{r}0.033 \mathrm{e} \\
+0002\end{array}$ & $\begin{array}{l}0.650^{\mathrm{b}} \\
+0020\end{array}$ & $\begin{array}{l} \pm 0.002 \\
0.056^{b}\end{array}$ \\
\hline & & & & & & & & & & \pm 0.003 \\
\hline Secamone afzelii & $\begin{array}{l}0.61^{\mathrm{e}} \\
\pm 0.020\end{array}$ & $\begin{array}{l}0.032^{c} \\
\pm 0.001\end{array}$ & $\begin{array}{l}1296.55^{c} \\
\pm 0.03\end{array}$ & $\begin{array}{l}0.95^{d} \\
\pm 0.02\end{array}$ & $\begin{array}{r}0.003^{b} \\
\pm 0.000\end{array}$ & $\begin{array}{r}0.005^{d} \\
\pm 0.000\end{array}$ & $\begin{array}{r}0.000^{d} \\
\pm 0.000\end{array}$ & $\begin{array}{l}0.048^{c} \\
\pm 0.001\end{array}$ & $\begin{array}{l}0.470^{d} \\
\pm 0.020\end{array}$ & $0.059 \mathrm{~b}$ \\
\hline $\begin{array}{l}\text { Calotropis } \\
\text { procera }\end{array}$ & $\begin{array}{c}0.33^{i} \\
\pm 0.055\end{array}$ & $\begin{array}{l}0.019^{f} \\
\pm 0.002\end{array}$ & $\begin{array}{l}32.66^{h} \\
\pm 0.03\end{array}$ & $\begin{array}{l}0.54^{h} \\
\pm 0.03\end{array}$ & $\begin{array}{l}0.000^{d} \\
\pm 0.02\end{array}$ & $\begin{array}{r}0.003^{f} \\
\pm 0.000\end{array}$ & $\begin{array}{r}0.004^{b} \\
\pm 0.000\end{array}$ & $\begin{array}{r}0.035 \mathrm{e}^{-} \\
\pm 0.002\end{array}$ & $\begin{array}{l}0.430^{\mathrm{e}} \\
\pm 0.010\end{array}$ & $\begin{array}{l}0.042^{d} \\
\pm 0.002\end{array}$ \\
\hline $\begin{array}{l}\text { Adansonia } \\
\text { digitata }\end{array}$ & $\begin{array}{l}0.71^{\mathrm{d}} \\
\pm 0.023\end{array}$ & $\begin{array}{l}0.026^{\text {de }} \\
\pm 0.001\end{array}$ & $\begin{array}{l}6.30 \mathrm{j} \\
\pm 0.02\end{array}$ & $\begin{array}{l}0.93^{d} \\
\pm 0.02\end{array}$ & $\begin{array}{l}0.000^{d} \\
\pm 0.000\end{array}$ & $\begin{array}{r}0.008^{\mathrm{a}} \\
\pm 0.000\end{array}$ & $\begin{array}{l}0.000^{d} \\
\pm 0.000\end{array}$ & $\begin{array}{r}0.070^{a} \\
\pm 0.003\end{array}$ & $\begin{array}{l}0.510^{c} \\
\pm 0.020\end{array}$ & $\begin{array}{r}0.051^{c} \\
\pm 0.002\end{array}$ \\
\hline $\begin{array}{l}\text { Lecaniodiscus } \\
\text { cupanioides }\end{array}$ & $\begin{array}{l}1.15^{a} \\
\pm 0.022\end{array}$ & $\begin{array}{l}0.016^{f g} \\
\pm 0.002\end{array}$ & $\begin{array}{l}33.62^{g} \\
\pm 0.02\end{array}$ & $\begin{array}{l}2.53^{a} \\
\pm 0.02\end{array}$ & $\begin{array}{l}0.003^{b} \\
\pm 0.000\end{array}$ & $\begin{array}{l}0.002 \mathrm{~g} \\
\pm 0.000\end{array}$ & $\begin{array}{l}0.003^{c} \\
\pm 0.000\end{array}$ & $\begin{array}{l}0.031^{f} \\
\pm 0.003\end{array}$ & $\begin{array}{l}0.000^{\mathrm{h}} \\
\pm 0.000\end{array}$ & $\begin{array}{r}0.034 \mathrm{e} \\
\pm 0.002\end{array}$ \\
\hline $\begin{array}{l}\text { Launaea } \\
\text { taraxacifolia }\end{array}$ & $\begin{array}{l}0.519 \\
\pm 0.031\end{array}$ & $\begin{array}{l}0.028^{d} \\
\pm 0.001\end{array}$ & $\begin{array}{l}796.25^{d} \\
\pm 0.02\end{array}$ & $\begin{array}{l}0.669 \\
\pm 0.04\end{array}$ & $\begin{array}{l}0.002^{c} \\
\pm 0.000\end{array}$ & $\begin{array}{l}0.006^{c} \\
\pm 0.000\end{array}$ & $\begin{array}{l}0.000^{d} \\
\pm 0.000\end{array}$ & $\begin{array}{l}0.035^{\mathrm{e}} \\
\pm 0.002\end{array}$ & $\begin{array}{l}0.380^{\mathrm{fg}} \\
\pm 0.010\end{array}$ & $\begin{array}{r}0.055^{b} \\
\pm 0.003\end{array}$ \\
\hline Senecio biafrae & $\begin{array}{l}0.46^{\mathrm{h}} \\
\pm 0.033\end{array}$ & $\begin{array}{l}0.035^{b} \\
\pm 0.001\end{array}$ & $\begin{array}{l}658.27^{f} \\
\pm 0.02\end{array}$ & $\begin{array}{l}0.74^{f} \\
\pm 0.03\end{array}$ & $\begin{array}{l}0.000^{d} \\
\pm 0.000\end{array}$ & $\begin{array}{r}0.006^{c} \\
\pm 0.000\end{array}$ & $\begin{array}{r}0.000^{d} \\
\pm 0.000\end{array}$ & $\begin{array}{l}0.041^{d} \\
\pm 0.003\end{array}$ & $\begin{array}{l}0.000^{\mathrm{h}} \\
\pm 0.000\end{array}$ & $\begin{array}{l}0.081^{a} \\
\pm 0.003\end{array}$ \\
\hline
\end{tabular}

Legend: Values are mean \pm SD of three replicates. Test values in the same column with same superscripts are not significantly different at $\mathrm{P}<0.05$.

Table 6 shows the inhibitory behaviour of the ten herbal galactogogues against six pathogenic organisms. Nine
(9) out of the 10 extracts were active against $E$. coli, the highest activity of $15.00 \mathrm{~mm}$ zone of inhibition was 
observed for $L$. cupanioides while the least was observed for $S$. biafrae $(11.0 \mathrm{~mm})$ and $K$. africana $(11.0 \mathrm{~mm})$ with no significant difference between them. Six (6) out of the 10 extracts were active on $K$. pneumoniae, the highest zones of inhibition was observed for $V$. doniana (21.0 $\mathrm{mm})$ and $K$. africana $(19.0 \mathrm{~mm})$ with no significant difference between them, the least was observed in $C$. procera $(11.0 \mathrm{~mm})$. The activity of $V$. doniana against $K$. pneumoniae agrees with the report of Egharevba et al. (2010). Four (4) of the ten extracts were active against $P$. aeruginosa, the highest activity of $17.0 \mathrm{~mm}$ zone of inhibition was observed for $L$. taraxacifolia. Three (3) of the ten extracts were active against $C$. albicans, but there was no significant difference between the zones of inhibition for A. digitata $(19.0 \mathrm{~mm})$, V. doniana $(17.0 \mathrm{~mm})$ and $C$. procera $(16.0 \mathrm{~mm})$. Some anti-candidal plants reported by Gbadamosi (2008) are Aristolochia bracteolata, Calliandra portoricensis, Curculigo pilosa, Gladiolus dalenii and Plumbago zeylanica. A. sessilis was the only plant extract active against $S$. pyogenes with $23.0 \mathrm{~mm}$ zone of inhibition. This might be an indication that it has component that could successfully inhibit the growth of $S$. pyogenes, since all the other extracts were not active against it. The antimicrobial activity of $A$. sessilis against $S$. pyogenes agrees with the report of Johnson et al. (2010) that the leaf extract had high activity against S. pyogenes. Three (3) of the 10 extracts were active against $S$. aureus, the highest activity of $19.00 \mathrm{~mm}$ zone of inhibition was observed for $A$. africanus while the lowest inhibition of $15 \mathrm{~mm}$ was observed for $L$. cupanioides. The high activity of $A$. africanus against $S$. aureus agrees with the finding of Sofidiya et al. (2011). The activity of Calotropis procera against E. coli, $S$. aureus, $P$. aeruginosa, and $C$. albicans agrees with the report of Goyal and Mathur (2011) that Calotropis procera has good inhibition against $E$. coli, $P$. aeruginosa, $S$. aureus and $C$. albicans.

Table 6: Inhibitory behaviour of ten botanical galactogogues against six pathogenic organisms ( $\left.10^{-3} \mathrm{cfu} / \mathrm{ml}\right)$

\begin{tabular}{|c|c|c|c|c|c|c|}
\hline \multirow[t]{2}{*}{$\begin{array}{l}\text { Plant extract } \\
(100 \mathrm{mg} / \mathrm{ml})\end{array}$} & $\begin{array}{l}\text { Escherichia } \\
\text { Coli }\end{array}$ & $\begin{array}{l}\text { Klebsiella } \\
\text { pneumoniae }\end{array}$ & $\begin{array}{l}\text { Pseudomonas } \\
\text { aeruginosa }\end{array}$ & $\begin{array}{l}\text { Candida } \\
\text { albicans }\end{array}$ & $\begin{array}{l}\text { Streptococcus } \\
\text { Pyogenes }\end{array}$ & $\begin{array}{l}\text { Staphylococcus } \\
\text { aureus }\end{array}$ \\
\hline & \multicolumn{6}{|c|}{ Zones of inhibition $(\mathrm{mm})$} \\
\hline Vitex doniana & $\begin{array}{l}* 13.00^{\mathrm{bc}} \\
\pm 1.00\end{array}$ & $\begin{array}{r}21.00^{\mathrm{a}} \\
\pm 1.51\end{array}$ & $\begin{array}{l}11.00^{c} \\
\pm 0.59\end{array}$ & $\begin{array}{l}17.00^{\mathrm{a}} \\
\pm 1.30\end{array}$ & - & - \\
\hline Kigelia africana & $\begin{array}{l}11.00 \mathrm{~d} \\
\pm 0.58\end{array}$ & $\begin{array}{r}19.00 \mathrm{a} \\
\pm 2.50\end{array}$ & - & - & - & - \\
\hline $\begin{array}{l}\text { Allophylus } \\
\text { africanus }\end{array}$ & $\begin{array}{c}14.00 \mathrm{ab} \\
\pm 0.00\end{array}$ & $\begin{array}{r}12.00^{\mathrm{b}} \\
\pm 0.58\end{array}$ & $\begin{array}{r}13.00^{\mathrm{b}} \\
\pm 1.20\end{array}$ & - & - & $\begin{array}{l}19.00^{\mathrm{a}} \\
\pm 4.00\end{array}$ \\
\hline $\begin{array}{l}\text { Alternanthera } \\
\text { sessilis }\end{array}$ & $\begin{array}{c}14.00 \mathrm{ab} \\
\pm 1.00\end{array}$ & $\begin{array}{r}13.00^{b} \\
\pm 0.60\end{array}$ & - & - & $\begin{array}{l}23.00^{a} \\
\pm 2.00\end{array}$ & $\begin{array}{l}16.00^{\mathrm{ab}} \\
\pm 3.10\end{array}$ \\
\hline Secamone afzelii & $\begin{array}{c}13.00 \mathrm{bc} \\
\pm 1.00\end{array}$ & $\begin{array}{r}12.00^{b} \\
\pm 1.30\end{array}$ & - & - & - & - \\
\hline $\begin{array}{l}\text { Calotropis } \\
\text { procera }\end{array}$ & $\begin{array}{c}13.00 \mathrm{bc} \\
\pm 1.20\end{array}$ & $\begin{array}{l}11.00^{b} \\
\pm 0.58\end{array}$ & $\begin{array}{r}11.00 c \\
\pm 0.40\end{array}$ & $\begin{array}{l}16.00^{a} \\
\pm 1.50\end{array}$ & - & - \\
\hline $\begin{array}{l}\text { Adansonia } \\
\text { digitata }\end{array}$ & - & - & - & $\begin{array}{l}19.00^{a} \\
\pm 1.00\end{array}$ & - & - \\
\hline $\begin{array}{l}\text { Lecaniodiscus } \\
\text { cupanioides }\end{array}$ & $\begin{array}{l}15.00^{a} \\
\pm 1.00\end{array}$ & - & - & - & - & $\begin{array}{l}15.00^{\mathrm{b}} \\
\pm 1.50\end{array}$ \\
\hline $\begin{array}{l}\text { Launaea } \\
\text { taraxacifolia }\end{array}$ & $\begin{array}{c}12.00 \mathrm{~cd} \\
\pm 1.00\end{array}$ & - & $\begin{array}{r}17.00^{\mathrm{a}} \\
\pm 2.53\end{array}$ & - & - & - \\
\hline $\begin{array}{l}\text { Senecio } \\
\text { biafrae }\end{array}$ & $\begin{array}{l}11.00^{d} \\
\pm 0.58\end{array}$ & - & - & - & - & - \\
\hline
\end{tabular}

Legends: $-=$ Not Active. * Values are mean \pm SD of three replicates. Test values in the same column with same superscripts are not significantly different at $\mathrm{P}<0.05$. 


\section{CONCLUSION}

The botanicals studied may not only act as galactogogues but have multifunctional effect such as provision of required nutrients, relief from constipation and prevention of infections in the nursing mothers. Most of the plants possess therapeutic potentials against $E$. coli and $K$. pneumoniae and they could be used as herbal drugs for the treatment of diarrhoea and pneumonia which reportedly are the main causes of child mortality

\section{REFERENCES}

Akindahunsi AA, and Salawu SO, 2005. Phytochemical screeninig, nutrient and anti-nutrient compositions of selected tropical green leafy vegetables. African Journal of Biochemistry 4 : 97-105.

Allen LH, and Graham JM, 2003. Assuring micronutrient adequacy in the diets of young infants. Micronutrient deficiencies in the first six months of life. Delange, F. M. and West, K. P. J. Eds. Basel: Vevey/S. Karger. 55-88.

AOAC, 2005. Official Methods of Analysis. 18th Edition. Association of Official Analytical Chemists, Washington, DC., USA.

Bruckner C, 1993. A survey on herbal galactogogues used in Europe. Medicaments et Aliments Heidelberg: L'Approche Ethnopharmacologique. pp. 140-145.

Chatterton RT, Hill PD, Aldag JC, Belknap SM, Jinman MJ, 2000. Relation of plasma oxytocin and prolactin concentrations to milk production in mothers of preterm infants: influence of stress. Journal of Clinical Endocrinal Metabolism 85(10):3661-3668.

Dike MC, 2010. Proximate, phytochemical and nutrient compositions of some fruits, seeds and leaves of some plant species at Umudike, Nigeria. Journal of Agricultural and Biological Science 5 (1):7-16.

Edeoga HO, Omobuna G, Uche LC, 2006. Chemical composition of Hyotis suaveoleus and Ocimum gratissimum hybrids from Nigeria. African Journal of Biotechnology 5(910): 892-895.

Egharevba HO, Ocheme OE, Ugbabe G, Abdullahi MS, lliya I, Okhale, ES, Kunle OF, Jemilat I, lbekwe N, Okwute SK, Okogun JI, 2010. Phytochemical Screening and Antimicrobial Studies of Methanol, Ethyl Acetate and Hexane Extracts of Vitex doniana Sweet. (Stem Bark and Leaf) Nature and Science 8(8): 177- 185. worldwide. The plants have potentials as food supplements for lactating mothers and babies due to their micronutrient and macronutrient constituents. A. digitata could also be used as weaning food due to its high calcium content. Further work should be done on isolation and identification of active compounds from the test plants. The toxicity test of the plant samples would guarantee their safety in administration.

Evans WC, 2002. Trease and Evans Pharmacognosy. 15th Edition. London: Bailliere Tindall. $585 \mathrm{pp}$.

FAO, 2003. Food energy-methods of analysis and conversion factors. Food and Nutrition Paper 77. Food and Agriculture Organization of the United Nations, Rome, Italy.

Gbadamosi IT, 2008. Ethnobotany and micropropagation of selected medicinal plants with $/ n$ vitro anticandidal activity in Ibadan, Southwest Nigeria. Ph.D dissertation. University of Ibadan. Ibadan Nigeria.

Goyal M. and Mathur R, 2011. Antimicrobial potential and phytochemical analysis of plant extracts of Calotropis Procera. International Journal of Drug Discovery and Herbal Research 1(3):138-143.

Harborne JB, 1973. Textbook of phytochemical methods. 1st ed. London: Chapman andHall Ltd. 288 pp.

Henderson, A. 2003.Domperidone: Discovering New Choices for Lactating Mothers.Association of Women's Health, Obstetric and Neonatal Nurses Lifeline 7:54-60.

Ishida, H., Suzuno, H., Sugiyama, N., Innami, S., Todokoro, T. and Maekawa, A. 2000. Nutritional evaluation of chemical component of leaves, stalks and stems of sweet potatoes (Ipomea batatas Poir). Food Chemistry 68: 359-367.

Iniaghe OM, Malomo SO, Adebayo JO, 2009. Proximate composition and phytochemical constituents of leaves of some Acalypha species. Pakistan Journal of Nutrition 8 (3): 256-258.

Jenness R, 1979. The Composition of Human Milk. Seminars in Perinatology 3: 225-239.

Johnson MI, Wesely EG, Selvan N, Kavitha MS, 2010. In vivo and In vitro anti-bacterial efficacy of Alternanthera sessilis (Linn.) International Journal of Pharmaceutical Research and Development 2(10) 72-79.

Kramer SM. and Kakuma R, 2002. The optimal duration of exclusive breast feeding a systematic review. 
Department of nutrition for health and development. WHO, Switzerland.

Lawrence R, 1999. Breastfeeding: A guide for the medical profession. St. Louis, MI: Mosby. 1128 pp.

Lioyd E, 2012. The Role of proteins in humans: How proteins help maintain life. Retrieved June 13, 2012, www.brighthub.com.

Lockett CT, Calvert CC, Grivetti LE, 2000. Energy and micronutrient composition of dietary and medicinal wild plants consumed during drought. Study of rural Fulani, North-eastern Nigeria. International Journal of Food Sciences and Nutrition 51:195-208.

Mohrbacher N. and Stock J, 2003. The Breastfeeding Answer Book. 3rd Edition (revised). Schaumburg: La Leche League International. $586 \mathrm{pp}$.

Newman J, 1995. How Breast Milk Protects New-borns. Scientific American 273 (6):76-79.

Nnamani CV, Oselebe HO, Agbatutu, A. 2009. Assessment of nutritional values of three underutilized indigenous leafy vegetables of Ebonyi State, Nigeria. African Journal of Biotechnology 8 (9):2321-2324.

Okwu DE, 2001. Evaluation of the chemical composition of indigenous spices and flavouring agents. Global Journal of Pure and Applied Science 7(3): 455- 459.

Okwu DE, and Okwu ME, 2004. Chemical composition of Spondias mombin Linn plant parts. Journal of Sustainable Agricultural Environment 6: 140147.

Osborne RJ, Slevin ML, Hunter RW, Hamer J, 1985. Cardiotoxicity of intravenous domperidone. Lancet 17:2(8451): 385.

Perry LM, 1980. Medicinal plants of East and Southeast Asia, Cambridge (Mass). London.

Riordan J. and Auerbach K, 1998. Human Lactation and Breastfeeding. 2nd Edition. Boston, MA: Jones \& Bartlett. 331-332 pp.

Sofidiya MO, Jimoh FO, Aliero AA, Afolayan AJ, Odukoya OA and Oluwole BF, 2011. Evaluation of antioxidant and antibacterial properties of six Sapindaceae members. Journal of Medicinal Plants Research 6(1)154-160.

Sofowora A, 1993. Medicinal Plants and Traditional Medicine in Africa. 2nd Edition. Ibadan, Nigeria: Spectrum Books Ltd. 289 pp .
Starr D. and Starr SE, 1999. Breastfeeding and adoption (Letter to the Editor). Journal of Human Lactation 15(3): 206-207.

Walsh LM, 1971. Instrumental methods for analysis of soils and plant tissue. Madison.Wis. USA: Soil Science society of America Inc. 222 pp.

Weimer J, 2001. The economic benefits of breastfeeding: a review and analysis food and rural economics division, economic research service, U.S. Department of Agriculture. Food assistance and nutrition research report No. 13.

Westfall RM, 2003. Galactogogue herbs: a qualitative study and review. Canadian Journal of Midwifery Research and Practice 2(2):22-27.

WHO, 2012. Ten facts on breastfeeding. Retrieved February 10, 2012, www.who.int/feature/factfile/breastfeeding/fact/e $\mathrm{n} /$.

Zuppa AA, Paola S, Claudia O, Chiara C, Valentina C, Costantino R, Piero C, 2010. Safety and efficacy of galactogogues: substances that induce, maintain and increase breast milk production. Journal of Pharmacology and Pharmaceutical Science 13(2):162 - 174. 